\title{
Molecular cloning of a novel bioH gene from an environmental metagenome encoding a carboxylesterase with exceptional tolerance to organic solvents
}

\author{
Yuping Shi ${ }^{1}$, Yingjie Pan ${ }^{1}$, Bailin $\mathrm{Li}^{1}$, Wei He${ }^{2}$, Qunxin She ${ }^{3}$ and Lanming Chen ${ }^{1 *}$
}

\begin{abstract}
Background: $\mathrm{BiOH}$ is one of the key enzymes to produce the precursor pimeloyl-ACP to initiate biotin biosynthesis de novo in bacteria. To date, very few bioH genes have been characterized. In this study, we cloned and identified a novel bioH gene, bioHx, from an environmental metagenome by a functional metagenomic approach. The bioHx gene, encoding an enzyme that is capable of hydrolysis of $p$-nitrophenyl esters of fatty acids, was expressed in Escherichia coli BL21 using the PET expression system. The biochemical property of the purified BioHx protein was also investigated.
\end{abstract}

Results: Screening of an unamplified metagenomic library with a tributyrin-containing medium led to the isolation of a clone exhibiting lipolytic activity. This clone carried a 4,570-bp DNA fragment encoding for six genes, designated biof, bioHx, fabG, bioC, orf5 and sdh, four of which were implicated in the de novo biotin biosynthesis. The bioHx gene encodes a protein of 259 aa with a calculated molecular mass of $28.60 \mathrm{kDa}$, displaying 24-39\% amino acid sequence identity to a few characterized bacterial BioH enzymes. It contains a pentapeptide motif $\left(\mathrm{Gly}_{76}-\mathrm{Trp}_{77}-\mathrm{Ser}_{78}-\mathrm{Met}_{79}-\mathrm{Gly}_{80}\right)$ and a catalytic triad $\left(\mathrm{Ser}_{78}-\mathrm{His}_{230}-\mathrm{Asp}_{202}\right)$, both of which are characteristic for lipolytic enzymes. BioHx was expressed as a recombinant protein and characterized. The purified BioHx protein displayed carboxylesterase activity, and it was most active on $p$-nitrophenyl esters of fatty acids substrate with a short acyl chain (C4). Comparing BioHx with other known BioH proteins revealed interesting diversity in their sensitivity to ionic and nonionic detergents and organic solvents, and BioHx exhibited exceptional resistance to organic solvents, being the most tolerant one amongst all known BioH enzymes. This ascribed BioHx as a novel carboxylesterase with a strong potential in industrial applications.

Conclusions: This study constituted the first investigation of a novel bioHx gene in a biotin biosynthetic gene cluster cloned from an environmental metagenome. The bioHx gene was successfully cloned, expressed and characterized. The results demonstrated that $\mathrm{BioHx}$ is a novel carboxylesterase, displaying distinct biochemical properties with strong application potential in industry. Our results also provided the evidence for the effectiveness of functional metagenomic approach for identifying novel bioH genes from complex ecosystem.

Keywords: BioH, Biotin biosynthetic pathway, Carboxylesterase, Metagenome, Aqueous environment

\footnotetext{
* Correspondence: Imchen@shou.edu.cn

'Key Laboratory of Quality and Safety Risk Assessment for Aquatic Products on Storage and Preservation (Shanghai), China Ministry of Agriculture, Engineering Centre for Quality Control and Risk Assessment of Aquatic Products, College of Food Science and Technology, Shanghai Ocean University, 999 Hu Cheng Huan Road, Shanghai 201306, P. R. China Full list of author information is available at the end of the article
} 


\section{Background}

Biotin (also known as vitamin $\mathrm{H}$, or B7) is an essential enzyme cofactor involved in multiple important metabolic pathways including fatty acids, amino acids, and carbohydrates in all three domains of life [1]. This coenzyme is synthesized de novo in microorganisms [2] where enzymes catalyzing the last four steps in the biotin biosynthesis are well characterized. These include 7-keto-8-aminopelargonic acid (KAPA) synthase, 7, 8-diaminopelargonic acid synthase, dethiobiotin synthetase, and biotin synthase. Their encoding genes, designated bioF, bioA, bioD and bioB, have been identified in $E$. coli [2,3]. More recently, two pathways, BioC-BioH and Biol, have been suggested for synthesizing pimeloyl-ACP (acyl carrier protein), an efficient substrate of BioF [2]. The BioI pathway is only present in Bacillus subtilis and its close relatives, where pimeloylACP is to be synthesized by an $\mathrm{O}_{2}$-dependent cleavage of long chain acyl-ACPs $[2,4]$. In the BioC-BioH pathway, BioC catalyzes $\mathrm{S}$-adenosylmethionine-dependent methylation of malonyl-CoA (or ACP) to malonyl-CoA (or ACP) methyl ester that enters fatty acid synthetic pathway, where an intermediate pimeloyl-ACP methyl ester was cleaved by $\mathrm{BioH}$ to produce pimeloyl-ACP that serves as the substrate for BioF to initiate biotin synthesis [2,5]. To date, bioH genes have been cloned from E. coli, Serratia marcescens, Serratia sp. and Kurthia sp. strains, and the encoded proteins exhibit carboxylesterase activity [6-9].

Esterases (EC 3.1.1.1) catalyze the hydrolysis of esters with short-chain fatty acids. They belong to the hydrolase superfamily with $\alpha / \beta$ protein fold [10], carrying a serine nucleophile embedded in the pentapeptide motif Gly-Xaa-Ser-Xaa-Gly [11] and the catalytic triad SerHis-Asp [12] at the catalytic site. Esterases, including lipases, are very important industrial enzymes and are widely applied in detergents and degreasing formulations, paper and leather manufacture, food processing, medical diagnostics and pharmaceutical syntheses, as well as wastewater treatment [13]. Microorganisms comprise the main resources of hydrolases from which most commercial hydrolases are derived [13]. This is mainly because microbes exhibit much great diversity than multicellular organisms. As a result, screening for novel hydrolases from microbe-rich environments have been of a great interest from both industrial and academic standpoints.

Since up to $99 \%$ of microorganisms in environments cannot be cultured by standard cultivation techniques according to taxonomic studies based on $16 \mathrm{~S}$ rRNA genes $[14,15]$, exploring esterase resources with any culturedependent methodology renders those resources untapped for uncultured microbes. Recently metagenomic technology was developed to address this problem. Utilizing this culture-independent approach, several genes encoding novel industrial enzymes, including lipases and esterases, have been obtained [16-19]. However, to our knowledge, hydrolase resources have not been explored for microbial communities in aquaculture environments, such as fishing pond sediments where diverse microorganisms thrive according to $16 \mathrm{~S}$ rRNA gene analysis (unpublished data). Here we report the cloning and identification of a bioH gene coding for an enzyme that is capable of hydrolysis of $p$-nitrophenyl $(p \mathrm{NP})$ esters of fatty acids by a functional metagenomic approach. A novel bioH, bioHx, was expressed, and the recombinant protein was purified and characterized. Our results indicate that $\mathrm{BioHx}$ is a novel carboxylesterase involved in the biotin biosynthesis, exhibiting good application potential in industry and biotechnological research.

\section{Results and discussion}

\section{Identification of a tributyrin-hydrolyzing clone from a} metagenomic library and sequence analysis of the cloned DNA fragment

Metagenomic DNA was prepared from sediment samples of aquaculture ponds. The resultant DNA were mechanically sheared by sonication, yielding DNA fragments of 2-9 $\mathrm{kb}$ that were used to construct a metagenomic library as described in Methods. To test the quality of the library, twenty transformants grown on LB-ampicillin agar plates were randomly picked up for plasmid preparation. Digestion of the purified plasmids with EcoRI indicated that they all contained an insert DNA fragment of 2-6 kb (data not shown), indicating the library was suitable for functional screening of industrial enzymes. In an esterase screening with Spirit Blue Agar plates containing tributyrin, one clone was found to produce a clear zone of hydrolysis on the selective plate amongst ca. 9,000 transformants yielded from the metagenomic library. This clone, designated pEstbioHx, was used for further studies.

The complete DNA sequence of the cloned fragment in pEstbioHx was determined, and deposited in the GenBank sequence database under the accession no. JX870139. It is 4,570-bp in length and contains six genes, designated bioF, bioHx, fabG, bioC, orf5 and sdh. Their gene organization is presented in Figure 1, in which the genes at the two ends were only recovered partly, i.e. the $5^{\prime}$ end of bioF and 3'end of $s d h$. Database searches revealed that the $4.5-\mathrm{kb}$ sequence displayed 91\% sequence identity at the nucleotide level over its full length with a DNA fragment of the Stenotrophomonas maltophilia R551 genome [GenBank: CP00111.1], indicating that the cloned DNA fragment could be derived from a $S$. maltophilia strain present in the fishing pond sediments. This is consistent to the notion that $S$. 


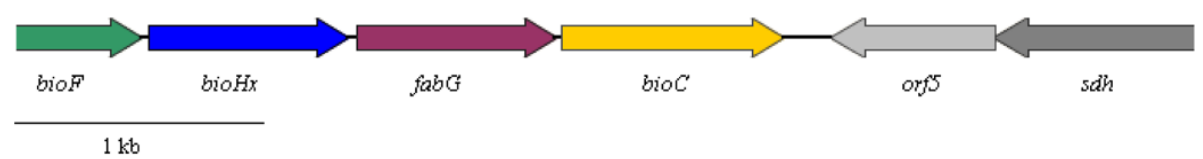

Figure 1 Gene organization of the sequenced 4,570-bp fragment cloned from an environmental metagenomic library. Six ORFs were identified, including: bioF, encoding 7-keto-8-aminopelargonic acid (KAPA) synthase; bioHx, encoding carboxylesterase; fabG, encoding 3-ketopimeloyl-ACP methyl ester reductase; bioC, encoding S-adenosylmethionine-dependent methyltransferase; orf5, encoding a DUF218 domain protein of unknown function; and sdh, encoding serine/threonine dehydratase.

maltophilia is ubiquitous in aqueous environments, soil and plants [20].

The gene responsible for the hydrolytic activity of tributyrin, was identified as bioHx positioned from 518 to 1297 in the cloned DNA fragment. bioHx encodes a protein of 259 aa, displaying high amino acid sequence similarities to putative carboxylesterase $\mathrm{BioH}$ identified from the complete genomes of Stenotrophomonas (9597\% identity) and Xanthomonas (70-73\% identity) species in the public databases. Much lower sequence similarities were found between $\mathrm{BioHx}$ and $\mathrm{BioH}$ enzymes of Escherichia coli $\mathrm{K} 12$ (38\% identity in a 233 aa stretch, [GenBank: P13001]) [6], Escherichia coli DH5 $\alpha$ (37\% identity in a 242 aa stretch, [PDB: 1M33]) [12], Serratia sp. SES-01 (38\% identity in a 250 aa stretch, [GenBank: ABY81653]) [6], Serratia marcescens Sr41 (39\% identity in a 250 aa stretch, [GenBank: Q8GHL1]) [7], and Kurthia sp. 538-KA26 (24\% in a 256 aa stretch, [GenBank: BAB39459]) [9], the only bacterial $\mathrm{BioH}$ that have been cloned and available in the databases. Analysis of these $\mathrm{BioH}$ proteins by multiple sequence alignment revealed that both the pentapeptide motif $\mathrm{Gly}_{76}-\mathrm{Trp}_{77^{-}}-\mathrm{Ser}_{78^{-}} \mathrm{Met}_{79^{-}}$ $\mathrm{Gly}_{80}$ and the catalytic triad $\mathrm{Ser}_{78}-\mathrm{His}_{230}-\mathrm{Asp}_{202}$ are conserved in BioHx (Figure 2).

As illustrated in Figure 1, the first 4 genes encoded in the cloned DNA fragment could form an operon with other biotin synthetic genes. The incomplete bioF gene $(<1-500 \mathrm{nt})$ is located upstream of $\mathrm{BioHx}$, coding for a

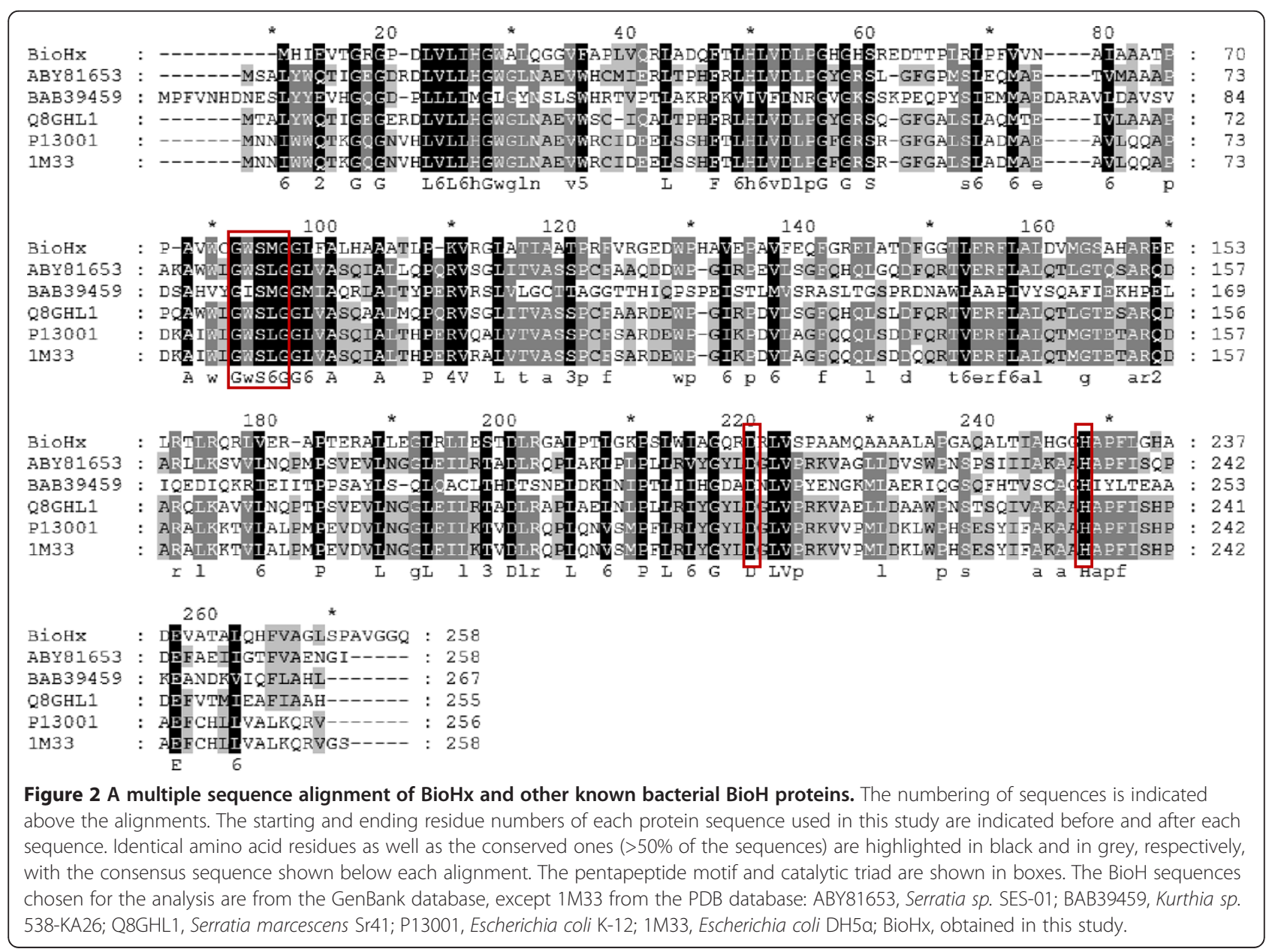


KAPA synthetase protein with an $\mathrm{N}$-terminal truncation. $\mathrm{BioF}$ is the enzyme catalyzing the first of the four-step reactions in biotin biosynthetic pathway. It synthesizes KAPA with pimeloyl-ACP and L-alanine [3]. The BioF displayed high sequence identities at the amino acid level to the same protein encoded in different bacteria including Stenotrophomonas (90-97\%) and Xanthomonas (69-75\%), as well as other bacteria, such as Xylella, Allochromoatium and Pseudomonas (51-69\%). There is a noncoding region of 17 bp separating biof from bioHx but it does not carry any recognizable motif for a putative promoter or a ribosomal binding site. Downstream of the bioHx lay fabG (1327-2103 nt) and bioC (2119-2985 nt) genes. The bioC encodes a protein of 294 amino acids, showing a high sequence similarity to a putative biotin biosynthesis protein BioC from Stenotrophomanas and close related species, while the deduced amino acid sequence of the 777-bp fabG gene exhibits a high level of sequence identity to putative 3-ketopimeloyl-ACP methyl ester reductases involved in fatty acid biosynthesis in the database. FabG reduces 3-ketopimeloyl-ACP methyl ester to 3-hydroxypimeloyl-ACP methyl ester in canonical fatty acid biosynthetic pathway, via which the intermediate pimeloyl-ACP methyl ester was produced and hydrolyzed by BioH to form pimeloyl-ACP substrate for BioF [3]. The intergenic regions are only for 29 and 15-bp starting from the second gene through the fourth with no identifiable putative promoters. Thus, biof, bioHx, fabG and bioC could be co-transcripted. Several other bacteria carry the same gene organization in the bioH region as for the cloned metagenomic fragment in which bioH is a member of the biotin biosynthetic operon [21]. But bioH genes in E. coli K12 and Serratia sp. SES-01 (denoted as bioHe and bioHs, respectively) are located elsewhere in the genomes [6]. Taken together, this reveals an interesting aspect of bacterial bioH diversity and evolution.

Two additional genes on the sequenced DNA fragment, orf5 (3798-3166 nt) and $s d h$ (4570-3795 nt) could have different functions. They are in the opposite orientation as for the first four genes. orf 5 encodes a protein of 210 aa, and its closest match was a protein family containing DUF218 domain. However, there is no clue that could lead to a possible function for this protein family in the current literature. The N-terminal truncated Sdh protein displayed a high degree of similarity with serine/threonine dehydratase, which functions in bacterial amino acid metabolism. As there is 3 bp overlap between the coding sequences of orf5 and $s d h$ genes, they could form an operon together with other unrecovered genes. It is thus interesting to study if orf5 could have any functional connection to $s d h$.

Based on the deduced amino acid sequences of $\mathrm{BioHx}$ and a selected set of its homologs identified in the public databases, a phylogenetic tree was constructed by the
MEGA4.0. This analysis revealed that these $\mathrm{BioH}$ sequences could form three families, designated I, II, and III (Figure 3). The BioH identified from E. coli, Serratia sp. and S. marcescens, as well as Kurthia sp. [6-9] were distributed in family I and III, respectively, whereas BioHx cloned in this study fell into cluster II, representing a novel BioH.

\section{Expression and purification of bioHx gene product}

The 777-bp bioHx structural gene (not including the stop codon) was amplified with primers BioHx-MF and BioHx$\mathrm{MR}$, the purified PCR product was digested with $\mathrm{BamHI}$ and HindIII, and then cloned into the expression vector pET-28a at BamHI and HindIII sites. The yielded recombinant plasmid, pET28a-bioHx, was transformed into E. coli BL21. $\mathrm{Kan}^{\mathrm{r}}$ transformants containing pET28abioHx were screened by colony PCR. BamHI and HindIII digests of the pET28a-bioHx verified that it carried the bioHx structural gene (data not shown).

A pET28a-bioHx transformant was grown in LBkanamycin medium. The expression of $\mathrm{BioHx}$ was induced by adding $0.6 \mathrm{mM}$ IPTG to the culture, and the induction was at $21^{\circ} \mathrm{C}$ for $20 \mathrm{~h}$. The cell-free extract containing the soluble target protein was analyzed by SDS-PAGE. As presented in Figure 4 (lane 3), one band corresponded in size to the calculated molecular mass of BioHx was detected. The band was absent in control lane from the E. coli BL21 cells carrying only the nonrecombinant pET28a vector (Figure 4, lane 2), which was cultured and induced under the same condition as that for the E. coli BL21 (pET28a-bioHx).

The expressed recombinant protein with six his-tags at $\mathrm{C}$-terminal was purified via a Ni-NTA His Bind resin column. Figure 4 (lane 4) shows the purified BioHx with molecular mass of approximately $29.27 \mathrm{kDa}$. Purified protein was about $82.70 \mathrm{mg}$ of per $1 \mathrm{~g}$ wet biomass, and accounted for about $1.8 \%$ of soluble total proteins in the cell-free extract.

\section{Effect of temperature and $\mathrm{pH}$ on BioHx activity and stability}

Carboxylesterase activity of the purified $\mathrm{BioHx}$ was determined for temperature range of 20 to $80^{\circ} \mathrm{C}$ using pNPbutyrate as the substrate. As presented in Figure $5 \mathrm{~A}$, BioHx displayed the maximal enzyme activity at $30^{\circ} \mathrm{C}$. The enzyme exhibited more than $74 \%$ of the optimal specific activity for the temperature range of $20-50^{\circ} \mathrm{C}$, indicating that it is moderately thermotolerant. However, enzyme activity declined rapidly when reaction temperatures reached above $70^{\circ} \mathrm{C}$. These results indicated that bioHx is a mesophilic enzyme.

To assess the effect of temperature on BioHx stability, the enzyme was exposed to a broad range of temperature for over $30 \mathrm{~min}$, and the residual activity was measured. 


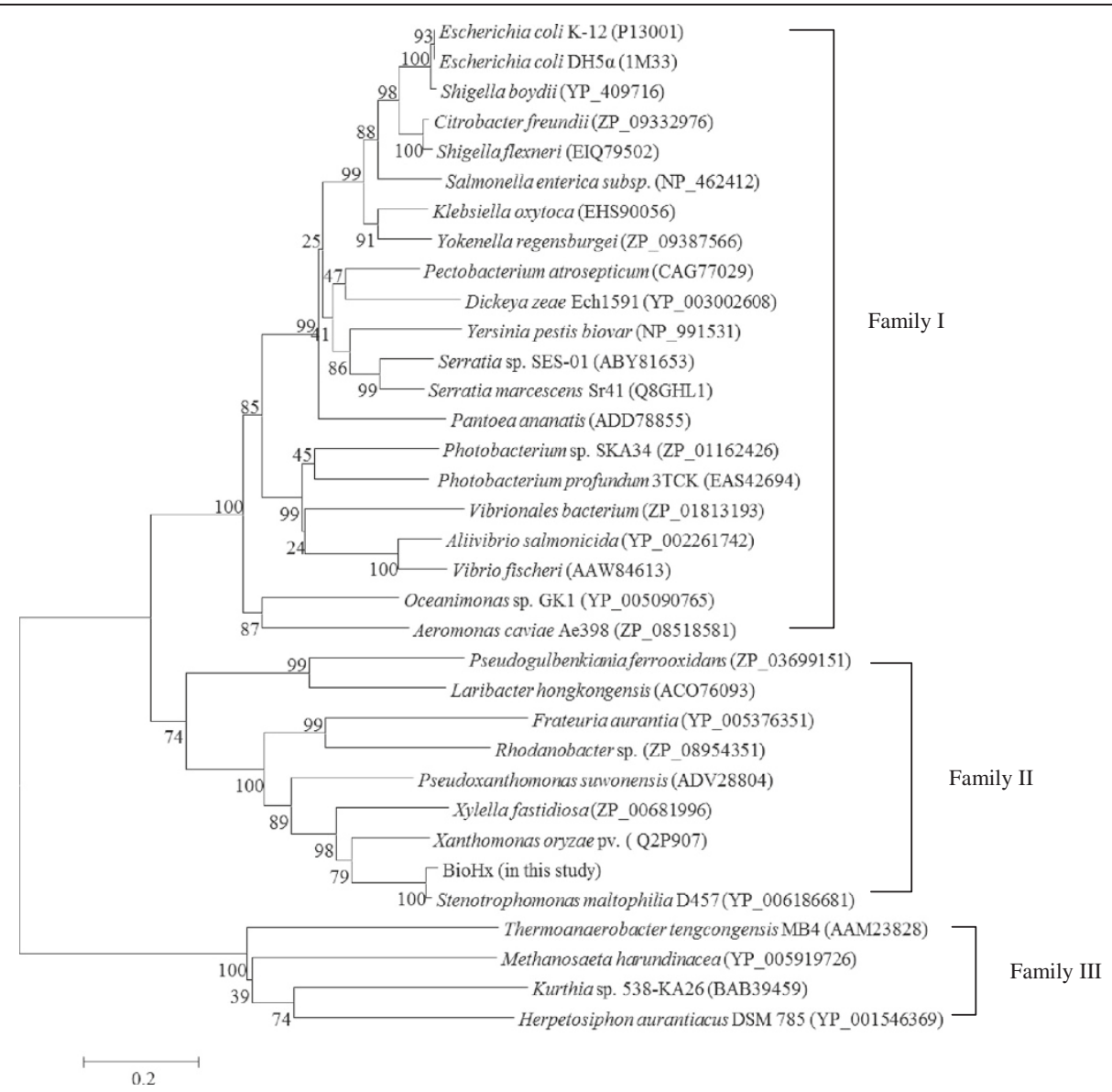

Figure 3 A phylogenetic tree showing evolutionary relationship between BioHx and a related set of BioH proteins identified in the public databases. The neighbor-joining phylogenetic tree was constructed using the software MEGA 4.0. Bootstrap percentages are shown at nodes. The scale bar represents 0.2 changes per amino acid.

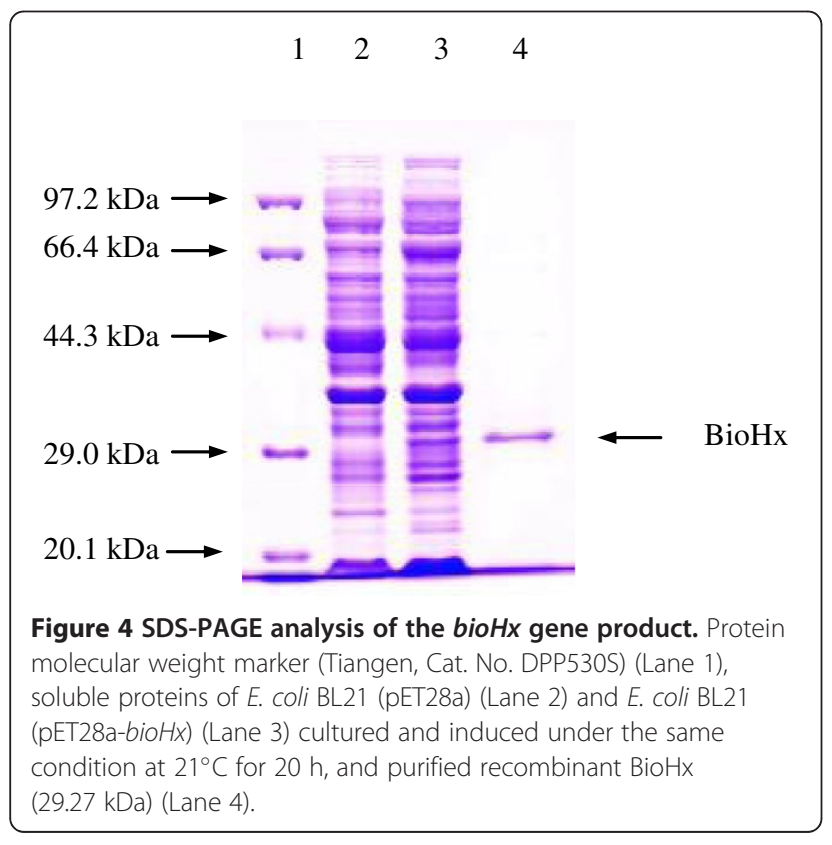

As shown in Figure 5B, BioHx showed considerable stability and retained $83-97 \%$ of its initial activity after the treatment at $10-50^{\circ} \mathrm{C}$. In addition, no loss in activity was observed after the enzyme was stored at $4^{\circ} \mathrm{C}$ for $12 \mathrm{~h}$ (data not shown).

The effect of $\mathrm{pH}$ on the BioHx activity was determined at $30^{\circ} \mathrm{C}$, the optimal reaction temperature. Purified BioHx was found to function in a range of $\mathrm{pH} 7.0-9.0$ with more than $50 \%$ of its maximal activity, and the $\mathrm{pH}$ optimum was recorded as $\mathrm{pH} 8.0$ (Figure 5C). Relative activity of BioHx declined sharply at the acidic range of $\mathrm{pH}$. The enzyme stability at various $\mathrm{pH}$ values was measured after incubating $\mathrm{BioHx}$ at $4^{\circ} \mathrm{C}$ for $12 \mathrm{~h}$. As shown in Figure 5D, the enzyme exhibited relatively strong stability at $\mathrm{pH}$ values ranging from neutral to alkaline conditions. It retained the maximal activity in the $\mathrm{pH}$ range of 6.0 to 8.0 , which dropped only slightly at $\mathrm{pH} 10$, indicating that the enzyme has a remarkable stability under alkaline conditions. 

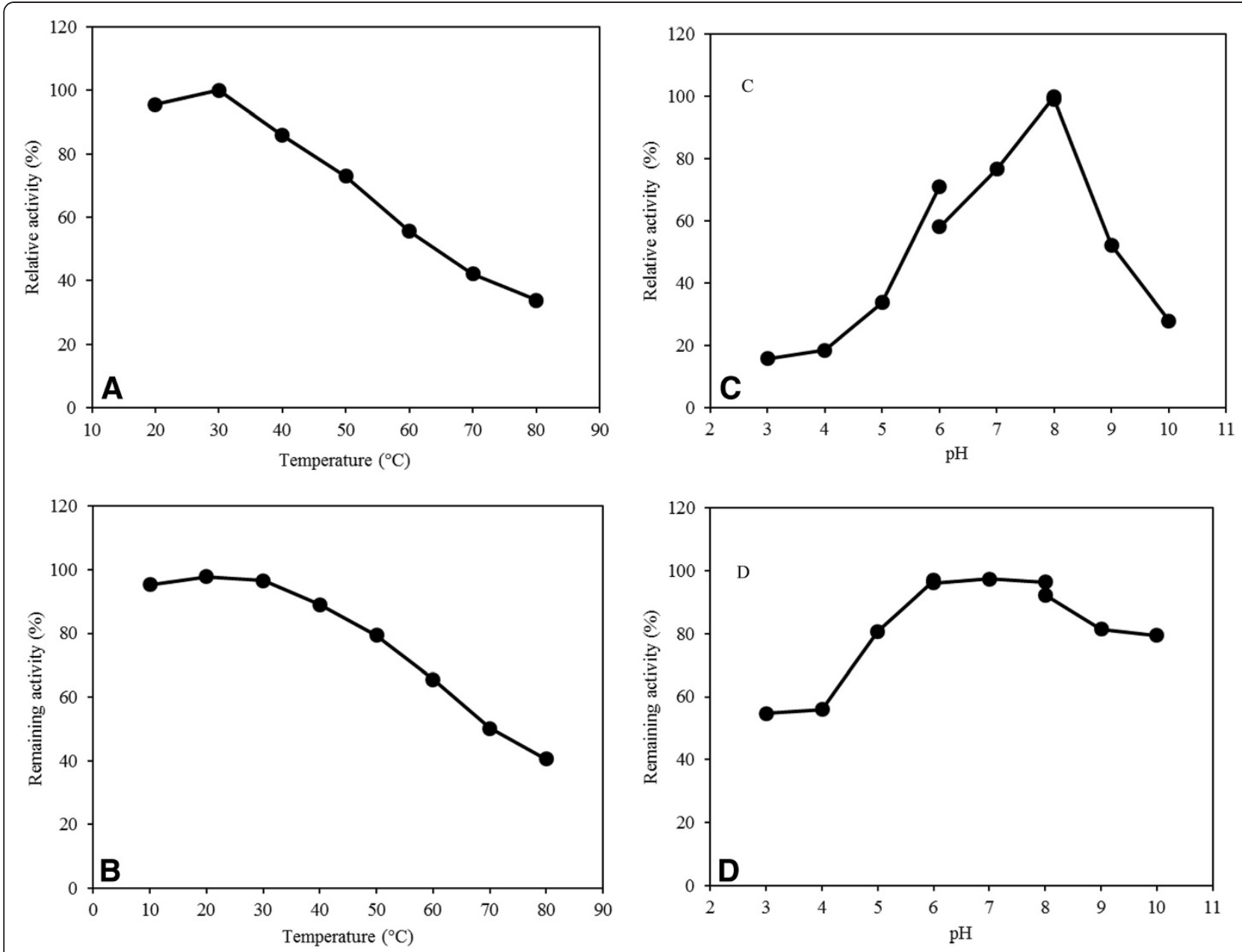

Figure 5 Effect of temperature and pH on BioHx activity and stability. Relative activity of purified BioHx was determined at different temperatures $(\mathbf{A})$ or $\mathrm{pH}(\mathbf{C})$ using pNP-butyrate as the substrate at $405 \mathrm{~nm}$. Remaining enzyme activity was measured at $30^{\circ} \mathrm{C}$ and $\mathrm{pH} 8.0$ after incubating purified BioHx at different temperatures for $30 \mathrm{~min}(\mathbf{B})$, or $\mathrm{pH}$ at $4^{\circ} \mathrm{C}$ for $12 \mathrm{~h}(\mathbf{D})$. All determinants were performed in triplicate.

\section{Substrate specification of BioHx}

Carboxylesterase activity of BioHx on $p$-nitrophenyl esters with acyl chain length of up to 12 carbons was assayed at $30^{\circ} \mathrm{C}$ and $\mathrm{pH}$ 8.0. As presented in Figure 6, BioHx displays highest activity $(2.7+/-0.3 \mu \mathrm{mol}$ es/ min - mg protein) on $p$ NP- butyrate (C4), followed by $89 \%$ relative activity on $p \mathrm{NP}-\mathrm{C} 2$, and $39-52 \%$ on $p \mathrm{NP}-$ C6 C8. These results are in a good agreement with those obtained with other bacterial BioH enzymes $[6,12]$. At structural level, the catalytic triad of E. coli $\mathrm{BioH}$ [PDB: 1M33] is buried between two domains and was not readily accessible for bulkier compounds [12]. This serves as a good explanation as to why $\mathrm{BioH}$ enzymes are more active on substrates with a short side chain.

It was reported that $\mathrm{BioH}$ encoded in E. coli showed a low enzymatic activity of thioesterase using palmitoyl$\mathrm{CoA}$ as a substrate [12]. Given that BioHx contained Gly $_{76}-\operatorname{Trp}_{77}-\mathrm{Ser}_{78}-\mathrm{Met}_{79}$-Gly 80 , a conserved motif for acyltransferases and thioesterases, we studied the

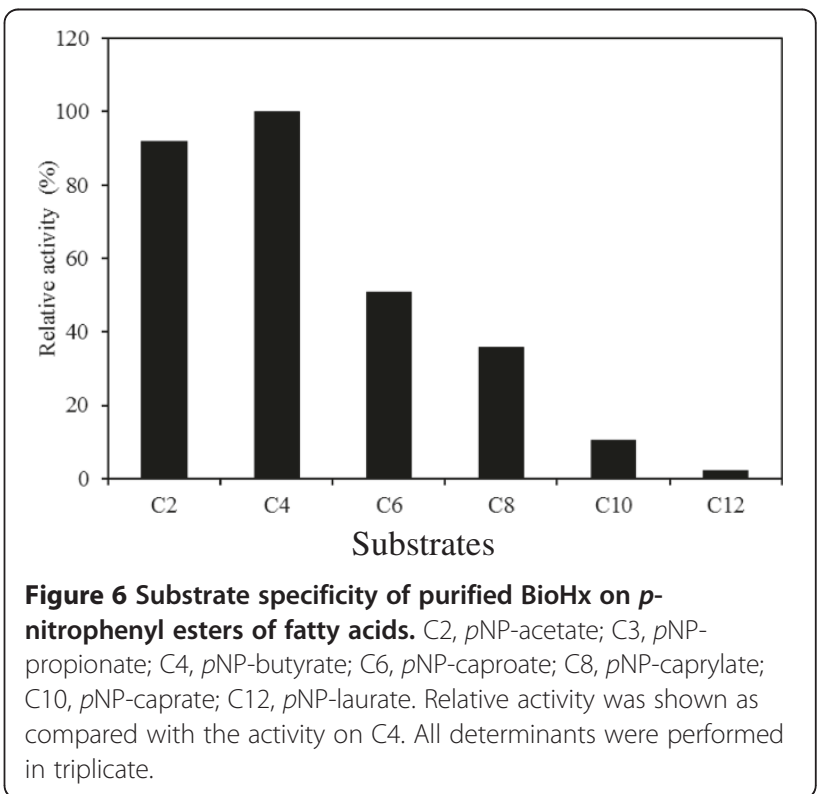


thioesterase activity of BioHx. The assay was carried out at $30^{\circ} \mathrm{C}$ and $\mathrm{pH} 8.0$ using palmitoyl-CoA as the substrate. BioHx showed a specific activity of $0.20+/-$ $0.08 \mu \mathrm{mol} \mathrm{CoA} / \mathrm{min} \cdot \mathrm{mg}$ protein on palmitoyl-CoA, which was approximately 13.4-times lower than its carboxylesterase activity on pNP-butyrate. The ratio of BioHx activities of hydrolyzing $p \mathrm{NP}$-esters/CoAthioester was similar to that of BioHs (11.6:1), but different from that of BioHe (33.3:1) [6].

\section{Effect of metal ions on BioHx stability}

To test the effect of divalent metal ions on BioHx activity, aliquots of the enzyme was incubated with $10 \mathrm{mM}$ of $\mathrm{ZnCl}_{2}, \mathrm{MnCl}_{2}, \mathrm{CaCl}_{2}, \mathrm{MgCl}_{2}, \mathrm{BaCl}_{2}$, and $\mathrm{CuSO}_{4}$ at $30^{\circ} \mathrm{C}$ for $1 \mathrm{~h}$, and residual activity was measured at $30^{\circ} \mathrm{C}$ and $\mathrm{pH} 8.0$ using pNP-butyrate as the substrate. As presented in Figure 7, compared with the control, $\mathrm{Ba}^{2+}$ and $\mathrm{Mn}^{2+}$ were found to increase enzyme activity by 20.5 and $39.2 \%$, respectively, whereas $\mathrm{Ca}^{2+}$ and $\mathrm{Cu}^{2+}$ showed a moderate inhibition to the enzyme as the activity declined to 77.7 and $59.5 \%$, respectively. $\mathrm{Mg}^{2+}$ and $\mathrm{Zn}^{2+}$ did not affect the enzyme activity. EDTA (10 mM) showed no effect on BioHx activity, suggesting that it is not a metalloenzyme. This is consistent with the results obtained with BioHe and BioHs [6].

\section{Effect of detergents and organic solvents on BioHx stability}

The effect of ionic and nonionic detergents on BioHx stability including sodium dodecyl sulfate (SDS), Tween 20 and Tween 80 was assayed. Similar with BioHe and BioHs, SDS strongly inhibited BioHx activity, diminishing about $80 \%$ of its activity at $0.5 \%$ concentration (Figure 7 ). In contrast to BioHe and BioHs in which their activities were

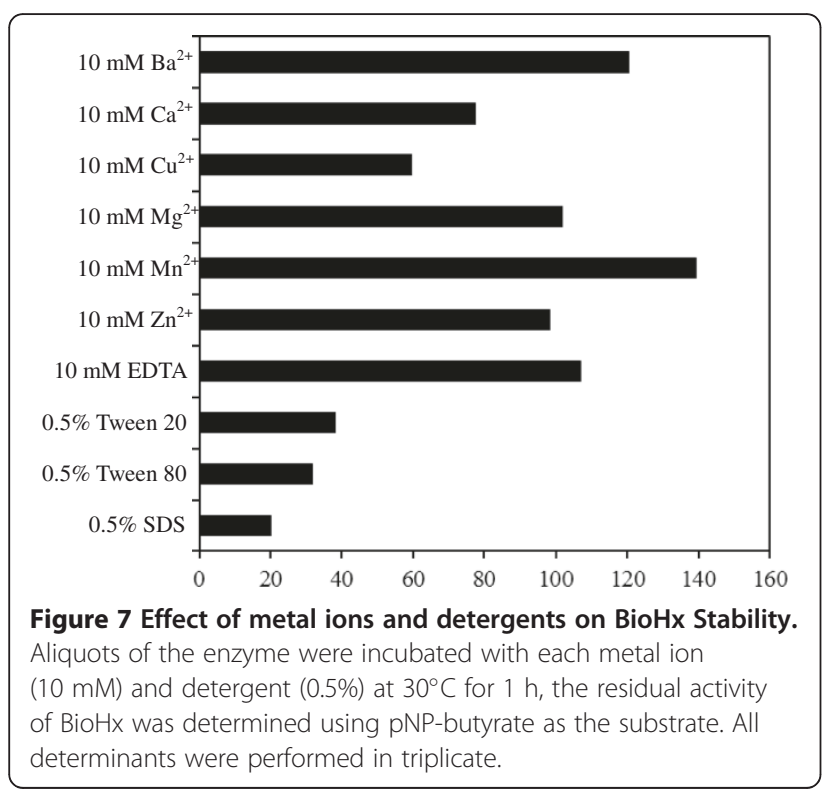

barely affected by $0.2-5 \%$ of Tween 20 and Tween 80 [6], the non-ionic detergents greatly reduced the BioHx activity, inhibiting more than $60 \%$ of its activity at a final concentration of $0.5 \%$, arguing for the diversity of $\mathrm{BioH}$ enzymes.

Tolerance to organic solvents is very important for any enzymes to be explored for industrial application. To study the stability of BioHx in organic solvents, the enzyme was individually incubated with methanol, ethanol, 2-propanol, 1-butanol, acetonitrile, acetone, dimethyl sulfoxide (DMSO) and dimethylformamide (DMF) at the indicated concentrations at $30^{\circ} \mathrm{C}$ for $1 \mathrm{~h}$. Residual activity of the treated enzymes was then determined under the standard assay condition. As summarized in Table 1, BioHx exhibited remarkable stability in methanol, DMSO and DMF, as it retained more than $90 \%$ of the original activity after the treatment with each of the organic solvents at a final concentration of $30 \%$. Organic solvent tolerance has been reported for BioHe and BioHs, from which different results have been obtained. BioHe shows strong resistance to treatments with $30 \%$ organic solvents, whereas BioHs lost more than 95\% activity under the same treatments [6]. However, compared with $\mathrm{BioHe}$, BioHx is more resistant to the treatments with $30 \%$ of 2-propanol or acetonitrile, as the residual activity of the treated $\mathrm{BioHx}$ is ca. 3-fold and 7-fold of that for BioHe. Furthermore, upon treatments with $50 \%$ 2-propanol or acetonitrile, BioHx still exhibits 76.2 or $44.3 \%$ residual activity (Table 1 ), indicating that it is very resistant to these organic solvents. These results reinforce that BioHx represents a novel $\mathrm{BioH}$ enzyme that is very suitable to be exploited for commercial application.

Although bioH genes are present in many microbial genomes in the public databases, very few BioH enzymes have been biochemically characterized to date. Among

Table 1 Effect of organic solvents on BioHx stability after incubation at $30^{\circ} \mathrm{C}$ for $1 \mathrm{~h}$

\begin{tabular}{ccccc}
\hline \multirow{2}{*}{$\begin{array}{l}\text { Organic } \\
\text { solvents }\end{array}$} & \multicolumn{4}{c}{ Residual activity (\%) } \\
\cline { 2 - 5 } & $\mathbf{2 0 \%}$ & $\mathbf{3 0 \%}$ & $\mathbf{4 0 \%}$ & $\mathbf{5 0 \%}$ \\
\hline Control & $100 \pm 0.10$ & $100 \pm 0.00$ & $100 \pm 0.00$ & $100 \pm 0.00$ \\
\hline Methanol & $94.6 \pm 3.2$ & $93.6 \pm 4.4$ & $85.5 \pm 2.3$ & $57.0 \pm 4.0$ \\
\hline Ethanol & $85.5 \pm 0.8$ & $82.2 \pm 3.2$ & $77.9 \pm 2.1$ & $75.4 \pm 4.1$ \\
\hline 2-Propanol & $86.3 \pm 3.2$ & $86.3 \pm 4.5$ & $76.8 \pm 4.4$ & $76.2 \pm 3.0$ \\
\hline 1-Butanol & $48.9 \pm 3.6$ & $47.9 \pm 3.0$ & $30.8 \pm 2.7$ & $23.5 \pm 2.2$ \\
\hline Acetonitrile & $74.4 \pm 1.2$ & $74.4 \pm 3.3$ & $65.0 \pm 4.3$ & $44.3 \pm 4.5$ \\
\hline Acetone & $79.6 \pm 1.9$ & $78.0 \pm 2.7$ & $62.1 \pm 3.7$ & $15.9 \pm 4.4$ \\
\hline DMSO & $95.7 \pm 2.4$ & $95.3 \pm 1.9$ & $54.2 \pm 1.0$ & $29.7 \pm 3.8$ \\
\hline DMF & $97.7 \pm 0.8$ & $97.3 \pm 1.3$ & $72.3 \pm 2.1$ & $19.7 \pm 1.1$ \\
\hline
\end{tabular}

No organic solvent was included in the control samples. The concentrations of organic solvents are indicated $(\mathrm{v} / \mathrm{v})$. The enzyme activity was determined under the standard assay condition, and the data is represented as an average of three independent determinations. 
them, interesting diversity of $\mathrm{BioH}$ enzymes is emerging, such as the great differences in organic solvent tolerance revealed for BioHe, BioHs and BioHx. In this regard, more $\mathrm{BioH}$ enzymes should be investigated both for elucidating biotin biosynthetic mechanisms in microorganisms and for exploiting them for commercial application in ester hydrolysis. There are three alternative approaches to select bioH genes for biochemical characterization: (1) identifying bioH genes from the public databases, (2) isolating microorganisms from environments for studying bioH, or (3) functional screening for bioH-containing clones from metagenomic libraries. Since functional screening of metagenomic libraries explore all microbes in environments where more than $90 \%$ of the resources are not represented in any culture-dependent approach and far more less resources are included in the public databases, we regard that the metagenomic approach represents the most rewarding research to explore industrial application of $\mathrm{BioH}$ enzymes.

\section{Conclusions}

In this study, a novel bioH gene, bioHx, in a 4,570-bp DNA fragment containing a biotin biosynthetic gene cluster was cloned and identified from an environmental metagenome by a functional metagenomic approach. The bioHx gene encodes a protein of 259 aa with a calculated molecular mass of $28.60 \mathrm{kDa}$, displaying $24-39 \%$ amino acid sequence identity to a few characterized bacterial BioH enzymes. BioHx was expressed as a recombinant protein in Escherichia coli BL21 using the pET expression system. The purified BioHx protein displayed carboxylesterase activity, and it was most active on $p$-nitrophenyl esters of fatty acids substrate with a short acyl chain (C4). Comparing BioHx with other known $\mathrm{BioH}$ proteins revealed interesting diversity in their sensitivity to ionic and nonionic detergents and organic solvents, and BioHx exhibited exceptional resistance to organic solvents, being the most tolerant one amongst all known BioH enzymes. The distinct biochemical properties positioned BioHx as a novel carboxylesterase with a good application potential in industry and biotechnological research.

\section{Methods}

\section{Bacterial strains, plasmids and culture conditions}

Escherichia coli TOP10 [genotype: $\mathrm{F}^{-}$mcrA $\Delta(m r r-$ hsdRMS-mcrBC) $\quad$ 80 lacZ $\Delta \mathrm{M} 15 \quad \Delta l a c \mathrm{X} 74 \quad$ recA1 araD139 $\Delta$ (ara-leu)7697 galU galK rpsL $\left(\mathrm{Str}^{\mathrm{R}}\right)$ endA1nupG] (TianGen Biotech Co. Ltd. Beijing, China) was used as a host strain for transformation of recombinant plasmids in the cloning. E. coli BL21(DE3) [genotype: $\mathrm{F}^{-}$ omp $\mathrm{T}$ hsd $\mathrm{S}_{\mathrm{B}}\left(r_{\mathrm{B}}^{-} m_{\mathrm{B}}^{-}\right)$gal $\left.\operatorname{dcm}(\mathrm{DE} 3)\right]$ (TianGen) was employed as a host for expression of recombinant proteins. The plasmid pUC19 (Fermentas, MD, USA) and
pET-28a (Merck Millipore, Darmstadt, Germany) were used as cloning and gene expression vector, respectively. E. coli host cells were grown in Luria-Bertani (LB) liquid medium [22] at $37^{\circ} \mathrm{C}$ with shaking at $200 \mathrm{rpm}$, while $E$. coli strains containing recombinant plasmids were cultured in LB broth or agar plates supplemented with ampicillin $(100 \mu \mathrm{g} / \mathrm{ml})$ or kanamycin $(30 \mu \mathrm{g} / \mathrm{ml})$.

\section{Extraction of metagenomic DNA from sediment in aquaculture ponds}

Sediment samples were collected from a few aquaculture ponds farming shrimp (Litopenaeus vannamei) located in Shanghai, China. Extraction of metagenomic DNA was carried out immediately after samples were transported to our laboratory in Shanghai Ocean University (Shanghai, China) according to the method of in situ lysis of microorganisms described by Zhou et al. [23]. A sediment sample $(50 \mathrm{~g})$ and $135 \mathrm{ml}$ DNA extraction buffer [100 mmol/l Tris-HC1, $100 \mathrm{mmol} / \mathrm{l}$ EDTA, $1.5 \mathrm{~mol} / \mathrm{l} \mathrm{NaC1}$ and 1\% (w/ v) hexadecyltrimethylammonium bromide (Sigma-Aldrich, MO, USA), pH8.0] were blended vigorously at $37^{\circ} \mathrm{C}$ for $30 \mathrm{~min}$. Then $0.5 \mathrm{ml}$ protease $\mathrm{K}(20 \mathrm{mg} / \mathrm{ml})$ and $2.0 \mathrm{ml}$ SDS (20\%) were added, and the mixture was incubated at $50^{\circ} \mathrm{C}$ for $3 \mathrm{~h}$ with gentle end-over-end inversions every 20 min. After centrifugation at $6,000 \mathrm{~g}$ for $10 \mathrm{~min}$ at $25^{\circ} \mathrm{C}$, the supernatant was collected and mixed with an equal volume of chloroform: isopropyl alcohol (24:1, by vol). The upper aqueous phase containing DNA was recovered by centrifugation at $12,000 \mathrm{~g}$ at $4^{\circ} \mathrm{C}$ for $10 \mathrm{~min}$, and DNA was precipitated by ethanol precipitation using 0.1 volume of $3 \mathrm{M}$ sodium acetate $(\mathrm{pH} 5.3)$ and 2 volumes of chilled anhydrous ethanol. To enhance the rate of DNA recovery, the mixed solution was held at $-20^{\circ} \mathrm{C}$ for $2 \mathrm{~h}$, and centrifugated at $13,000 \mathrm{~g}$ for $15 \mathrm{~min}$ at $4^{\circ} \mathrm{C}$. DNA pellet was washed with $70 \%$ ethanol, and resuspended in $200 \mu \mathrm{l}$ sterilized Mili-Q water (Millipore Billerica, MA, USA). The isolated DNA was further purified using Wizard DNA Clean-Up System (Promega, WI, USA) according to the manufacturer's instruction. The concentration of DNA in the samples was determined using a multi-mode microplate reader BioTek Synergy ${ }^{\mathrm{TM}} 2$ (BioTek Instruments, Inc., VT, USA).

\section{Construction of metagenomic library and screening for tributyrin-hydrolyzing clones}

Purified metagenomic DNA was sheared mechanically by sonication for appropriate lengths of time established by pilot experiments to generate 2-9 kb DNA fragments. The fragments were separated by agarose gel electrophoresis and recovered from the gel matrix using Axygen gel extraction kit (Axygen, CA, USA). The purified fragments were blunted at $5^{\prime}$ and 3 'ends with T4 DNA polymerase and DNA Polymerase I (Large Klenow Fragment) (New England BioLabs, MA, USA), and then 
ligated to a pUC19 vector at smaI site according to the instructions of the manufactures. Ligation was preformed in a $10 \mu \mathrm{l}$ reaction volume with a molar ratio of vector: insert of $1: 3$, and incubated at $16^{\circ} \mathrm{C}$ overnight, yielding an unamplified metagenomic library. This was then used to transform E. coli TOP 10 competent cells via the heat-shock method [22]. A $100 \mu \mathrm{l}$ of transformed cell suspension was spread onto selective Spirit Blue Agar (Sigma-Aldrich) plates containing 1\% tributyrin (Sigma-Aldrich), 0.05\% Tween 80 (Sigma-Aldrich) and $100 \mu \mathrm{g} / \mathrm{ml}$ ampicillin. Plates were incubated at $37^{\circ} \mathrm{C}$ for $48 \mathrm{~h}$, and white colonies with a clear zone of hydrolysis were candidates for identifying esterase genes. Library quality was assessed by spreading $100 \mu \mathrm{l}$ of transformation culture onto LB-ampicillin agar plate containing $40 \mu \mathrm{l}$ 5-bromo-4-chloro-3-indolyl- $\beta$-Dgalactopyran-oside (X-gal, $20 \mathrm{mg} / \mathrm{ml}$ ), and $16 \mu \mathrm{l}$ isopropyl$\beta$-D-thiogalactopyranoside (IPTG, $50 \mathrm{mg} / \mathrm{ml}$ ). Plates were incubated at $37^{\circ} \mathrm{C}$ overnight, and white colonies were randomly selected for further analysis.

\section{Sequence analyses}

Plasmid DNA of positive library clones was isolated using MiniBEST plasmid purification kit (TaKaRa Biotechnology Co. Ltd. Dalian, China). Automated DNA sequencing was carried out using ABI 3730XL capillary sequencer (Applied Biosystems, CA, USA) and BigDye ${ }^{\circledR}$ terminator version 3.1 cycle sequencing kit (Perkin-Elmer, MA, USA) at the China Human Genome Centre (Shanghai, China). Oligonucleotide primers were synthesized by Shanghai Sangon Biological Engineering Technology and Services Co., Ltd. (Shanghai, China).

Sequencing reads were assembled using the ContigExpress software (http://www.contigexpress.com/). Putative functions were inferred using the Basic Local Alignment Search Tool (BLAST) (http://www.ncbi.nlm.nih. gov/BLAST) and ORF finder (http://www.ncbi.nlm.nih.gov/ gorf). Multiple sequence alignments were performed using the ClustalW2 software (http://www.ebi.ac.uk/Tools/msa/ clustalw2/) [24]. The neighbor-joining method in the molecular evolutionary genetic analysis software package MEGA (version 4.0) [25] was used to construct a phylogenetic tree. A bootstrap analysis with 1000 replicates was carried out to check the reliability of the tree.

\section{Expression of bioHx in E. coli and purification of the recombinant protein}

Based on the sequence obtained in this study, specific primers BioHx-MF (5' - CGCGGATCCATGCATATT GAAGT-3') and BioHx-MR (5'-CCCAAGCTTTTGTC CGCCA-3') targeting bioHx structural gene were designed using the software Primer 5.0 (http://www. premierbiosoft.com/). Restriction endonuclease $\mathrm{BamHI}$ and HindIII digestion sites were designed and indicated by underlined sequences, respectively. PCR amplification was performed in a $20 \mu \mathrm{l}$ reaction volume containing $1 \times$ PrimeSTAR $^{\circledR}$ MAX Premix (TaKaRa), $5 \mu \mathrm{M}$ each of primers, and approximately $10 \mathrm{ng}$ template DNA. PCR reactions were carried out under the following condition according to the instructions of the supplier: 30 cycles consisting of $98^{\circ} \mathrm{C}$ for $10 \mathrm{~s}, 55^{\circ} \mathrm{C}$ for $5 \mathrm{~s}$, and $72^{\circ} \mathrm{C}$ for 10s; and a final extension of $72^{\circ} \mathrm{C}$ for $5 \mathrm{~min}$. Amplification was performed in a Mastercycler ${ }^{\circledR}$ pro PCR thermal cycler (Eppendorf, Hamburg, Germany). A sample (5 $\mu \mathrm{l})$ of each amplification reaction was analyzed by electrophoresis on a $1.0 \%$ agarose gel.

The desired amplicon was purified, and digested with the two restriction endonucleases (Promega) at $37^{\circ} \mathrm{C}$ according to the instructions of the supplier. Restriction fragment was then purified, and ligated into the expression vector pET-28a that was digested with the same endonucleases. Ligation DNA was transformed into $E$. coli BL21 competent cells by the heat-shock method. Transformants grown on LB-kanamycin agar plates were identified by colony PCR assay. Plasmid DNA of positive transformants were isolated and digested with $\mathrm{BamHI}$ and HindIII. Recombinant plasmid, pET28a-bioHx, was used for protein expression analysis.

When E. coli BL21 carrying pET28a-bioHx was grown in LB-kanamycin broth at $37^{\circ} \mathrm{C}$ to $\mathrm{OD}_{600}$ 0.3-0.6, IPTG was added to a final concentration of $0.6 \mathrm{mM}$, and the cells were cultured at $21^{\circ} \mathrm{C}$ for additional $20 \mathrm{~h}$. The cells were harvested by centrifugation at $10,000 \mathrm{~g}$ for $10 \mathrm{~min}$ at $4^{\circ} \mathrm{C}$, and then resuspended in 5-fold of BugBuster protein extraction reagent (Merck Millipore), followed by incubation at $25^{\circ} \mathrm{C}$ for $20 \mathrm{~min}$. The suspension was incubated on ice for $30 \mathrm{~min}$, and then sonicated five times each for $3 \mathrm{sec}$. The cell lysate was centrifuged at $16,000 \mathrm{~g}$ for $20 \mathrm{~min}$ at $4^{\circ} \mathrm{C}$, and the supernatant containing soluble target protein was collected and analyzed by one-dimensional sodium dodecyl sulfate-polyacrylamide gel electrophoresis (SDSPAGE) with $12 \%$ separation gel and $5 \%$ stacking gel using a Mini-PROTEAN ${ }^{\circledR}$ electrophoresis cell (Bio-Rad). Following electrophoresis, the gel was stained with $0.25 \%$ Coomassie brilliant blue R250 and then destained according to the standard method [22].

The cell-free extract was purified using Ni-NTA His. Bind $^{\circledR}$ resin (Merck Millipore) according to the supplier's instructions. The resulting protein fractions were collected and analyzed by SDS-PAGE. Protein concentration was determined using BCA protein assay kit (Sangon) with bovine serum albumin as the standard. The E. coli BL21 carrying the vector pET28a was used as a control.

\section{Characterization of $\mathrm{BioHx}$}

Purified BioHx was subjected to several biochemical assays including substrate specificity, optimum temperature and $\mathrm{pH}$, and effects of organic solvents, detergents and metal ions on enzyme stability. The data was expressed as an 
average of the results from triplicate assays. Carboxylesterase activity of $\mathrm{BioHx}$ was measured spectrophotometrically according to the method described by Min-A et al. [6], using $p$-nitrophenyl $(p \mathrm{NP})$ butyrate $(\mathrm{C} 4)$ or $p \mathrm{NP}$ esters of other fatty acids (C2-C12) (Sigma-Aldrich) as the substrates. Purified enzyme was appropriately diluted to $50 \mu \mathrm{l}$ and incubated with a $200 \mu \mathrm{l}$ reaction mixture containing $10 \mathrm{mM} p$-NP butyrate or other $p \mathrm{NP}$ esters, ethanol, and $50 \mathrm{mM}$ Tris- $\mathrm{HCl}$ (pH 8.0) at 1:4:95 (by vol). The amount of $p$-nitrophenol released from $p \mathrm{NP}$ esters at $30^{\circ} \mathrm{C}$ was monitored at $405 \mathrm{~nm}$ for 10 min using a spectrophotometer Synergy ${ }^{\mathrm{TM}} 2$ (BioTek). One unit of enzyme activity was defined as the amount of enzyme capable of releasing $1 \mu \mathrm{mol}$ of p-nitrophenol esters per minute. Thioesterase activity was measured according to the method described by Watanabe et al. [26] using palmitoyl-CoA (ACP) as the substrate.

The optimum temperature for enzyme activity was determined at temperatures between 20 and $80^{\circ} \mathrm{C}$ at $\mathrm{pH}$ 8.0 using $p$-NP butyrate as the substrate. The thermostability of BioHx was assayed by incubating aliquots of purified $\mathrm{BioHx}$ at various temperatures $\left(10\right.$ to $\left.80^{\circ} \mathrm{C}\right)$ for $30 \mathrm{~min}$. The residual activities were measured at $30^{\circ} \mathrm{C}$. The effect of $\mathrm{pH}$ on enzyme activity was investigated at $30^{\circ} \mathrm{C}$ at the $\mathrm{pH}$ range of 3.0 to $10.0,50 \mathrm{mM}$ sodium citrate was used for $\mathrm{pH} 3.0-6.0,50 \mathrm{mM}$ sodium phosphate for $\mathrm{pH}$ 6.0-8.0 and $50 \mathrm{mM}$ Tris- $\mathrm{HCl}$ for $\mathrm{pH}$ 8.0-10.0 [6]. The $\mathrm{pH}$ stability of the enzyme was evaluated by incubating $\mathrm{BioHx}$ at various $\mathrm{pH}$ values $(3.0-10.0)$ at $4^{\circ} \mathrm{C}$ for $12 \mathrm{~h}$. The residual enzyme activity was determined under standard condition at $30^{\circ} \mathrm{C}$ and $\mathrm{pH} 8.0$ using the $p$-NP butyrate substrate.

The stability of purified BioHx in the presence of metal ions $(10 \mathrm{mM})$, detergents $(0.25-0.5 \%)$ and organic solvents (20-50\%) was determined by incubation of the enzyme with various reagents at $30^{\circ} \mathrm{C}$ for $1 \mathrm{~h}$, residual enzyme activity was measured under the standard condition.

\section{Competing interests}

The authors declare that they have no competing interests.

\begin{abstract}
Authors' contributions
YS, YP, BL and LC participated in the design of the study; YS carried out the major experiments, and HW carried out DNA sequencing; YS, YP, BL and LC analyzed data; LC drafted the manuscript, and QS revised it for important intellectual content and improvement; YS, YP, BL, HW, QS and LC read and approved the final manuscript to be published.
\end{abstract}

\section{Acknowledgements}

This work was supported by Grants No.09320503600 and No.10PJ1404900 from Shanghai Municipal Science and Technology Commission, a Grant No. B-9500-10-0004 and a Leading Academic Discipline Project (No. J50704) from Shanghai Municipal Education Commission.

\section{Author details}

${ }^{1}$ Key Laboratory of Quality and Safety Risk Assessment for Aquatic Products on Storage and Preservation (Shanghai), China Ministry of Agriculture, Engineering Centre for Quality Control and Risk Assessment of Aquatic Products, College of Food Science and Technology, Shanghai Ocean
University, 999 Hu Cheng Huan Road, Shanghai 201306, P. R. China. ${ }^{2}$ Shanghai Hanyu Bio-lab, 151 Ke Yuan Road, Shanghai 201203, P.R. China. ${ }^{3}$ Department of Biology, University of Copenhagen, Ole Maaloes Vej 5, Copenhagen 2200 N, Denmark.

Received: 9 October 2012 Accepted: 25 January 2013 Published: 15 February 2013

\section{References}

1. Tong L: Structure and function of biotin-dependent carboxylases. Cell Mol Life Sci 2012, in press.

2. Cronan JE, Lin S: Synthesis of the $a, \omega$-dicarboxylic acid precursor of biotin by the canonical fatty acid biosynthetic pathway. Curr Opin Chem Biol 2011, 15:407-413.

3. Lin S, Hanson RE, Cronan JE: Biotin synthesis begins by hijacking the fatty acid synthetic pathway. Nat Chem Biol 2010, 6(9):682-688.

4. Bower S, Perkins JB, Yocum RR, Howitt CL, Rahaim P, Pero J: Cloning, sequencing, and characterization of the Bacillus subtilis biotin biosynthetic operon. J Bacterio/ 1996, 178:4122-4130.

5. Shapiro MM, Chakravartty V, Cronan JE: Remarkable diversity in the enzymes catalyzing the last step in synthesis of the pimelate moiety of biotin. PLoS One 2012, 7(11):e49440.

6. Min-A K, Kim HS, Oh JY, Song BK, Song JK: Gene cloning, expression, and characterization of a new carboxylesterase from Serratia sp. SES-01: comparison with Escherichia coli BioHe Enzyme. J Microbiol Biotechnol 2009, 19(2):147-154.

7. Akatsuka H, Kawai E, Imai Y, Sakurai N, Omori K: The Serratia marcescens bioH gene encodes an esterase. Gene 2003, 302:185-192.

8. Tomczyk NH, Nettleship JE, Baxter RL, Crichton HJ, Webster SP, Campopiano DJ: Purification and characterisation of the $\mathrm{BIOH}$ protein from the biotin biosynthetic pathway. FEBS Lett 2002, 513:299-304.

9. Kiyasu T, Nagahashi Y, Hoshino T: Cloning and characterization of biotin biosynthetic genes of Kurthia sp. Gene 2001, 265:103-113.

10. Ollis DL, Cheah E, Cygler M, Dijkstra BW, Frolow F, Franken SM, Harel M, Remington SJ, Silman I, Schrag J, Sussman JL, Verschueren KHG, Goldman A: The alpha/beta hydrolase fold. Protein Eng 1992, 5:197-211.

11. Arpigny JL, Jaeger K-E: Bacterial lipolytic enzymes: classification and properties. Biochem J 1999, 343:177-183.

12. Sanishvilia R, Yakunin AF, Laskowski RA, Skarina T, Evdokimova E, Doherty-Kirby A, Lajoie GA, Thornton JM, Arrowsmith CH, Savchenko A, Joachimiak A, Edwards AM: Integrating structure, bioinformatics, and enzymology to discover function: $\mathrm{BioH}$, a new carboxylesterase from Escherichia coli. J Biol Chem 2003, 278(28):26039-26045.

13. Sharmaa R, Chistib Y, Banerjee UC: Production, purification, characterization, and applications of lipases. Biotechnol Adv 2001, 19:627-662.

14. Amann Rl, Ludwig W, Schleifer KH: Phylogenetic identification and in situ detection of individual microbial cells without cultivation. Microbio/ Rev 1995, 59:143-169.

15. Rondon MR, August PR, Bettermann AD, Brady SF, Grossman TH, Liles MR, Loiacono KA, Lynch BA, MacNeil IA, Minor C, Tiong CL, Gilman M, Osburne MS, Clardy J, Handelsman J, Goodman RM: Cloning the soil metagenome: a strategy for accessing the genetic and functional diversity of uncultured microorganisms. Appl Environ Microbiol 2000, 66:2541-2547

16. Chu X, He H, Guo C, Sun B: Identification of two novel esterases from a marine metagenomic library derived from South China Sea. Appl Microbiol Biotechnol 2008, 80(4):615-625.

17. Ferrer M, Golyshina OV, Chernikova TN, Khachane AN, Reyes-Duarte D, Santos VA, Strompl C, Elborough K, Jarvis G, Neef A, Yakimov MM, Timmis KN, Golyshin PN: Novel hydrolase diversity retrieved from a metagenome library of bovine rumen microflora. Environ Microbiol 2005, 7(12):1996-2010.

18. Hong KS, Lim HK, Chung EJ, Park EJ, Lee MH, Kim JC, Choi GJ, Cho KY, Lee SW: Selection and characterization of forest soil metagenome genes encoding lipolytic enzymes. J Microbiol Biotechnol 2007, 17(10):1655-1660.

19. Kang $\mathrm{C}-\mathrm{H}$, Oh $\mathrm{K}-\mathrm{H}$, Lee $\mathrm{M}-\mathrm{H}$, Oh T-K, Kim BH, Yoon J-H: A novel family VII esterase with industrial potential from compost metagenomic library. Microbial Cell Factories 2011, 10:41.

20. Berg G, Roskot N, Smalla K: Genotypic and phenotypic relationships between clinical and environmental isolates of Stenotrophomonas maltophilia. J Clin Microbiol 1999, 37(11):3594-6000. 
21. Rodionov DA, Mironov AA, Gelfand MS: Conservation of the biotin regulon and the BirA regulatory signal in Eubacteria and Archaea. Genome Res 2002, 12:1507-1516.

22. Sambrook J, Russell DW: Molecular Cloning: A Laboratory Manual. New York: Cold Spring Harbor Press; 2001.

23. Zhou J, Bruns MA, Tiedje JM: DNA Recovery from soils of diverse composition. Appl Environ Microbiol 1996, 62(2):316-322.

24. Larkin MA, Blackshields G, Brown NP, Chenna R, NcGettigan PA, McWilliam H, Valentin F, Wallace IM, Wilm A, Lopez R, Thompson JD, Gibson TJ, Higgins DG: Clustal W and Clustal X version 2.0. Bioinformatics 2007, 23:2947-2948.

25. Tamura K, Dudley J, Nei M, Kumar S: MEGA4: molecular evolutionary genetics analysis (MEGA) software version 4.0. Mol Biol Evol 2007, 24:1596-1599.

26. Watanabe H, Shiratori T, Shoji H, Miyatake S, Okazaki Y, Ikuta K, Sato T, Saito T: A Novel acyl-CoA Thioesterase Enhances Its Enzymatic Activity by Direct Binding with HIV Nef. Biochem Biophys Res Commun 1997, 238:234-239.

Cite this article as: Shi et al:: Molecular cloning of a novel bioH gene from an environmental metagenome encoding a carboxylesterase with exceptional tolerance to organic solvents. BMC Biotechnology 2013 13:13.

\section{Submit your next manuscript to BioMed Central and take full advantage of:}

- Convenient online submission

- Thorough peer review

- No space constraints or color figure charges

- Immediate publication on acceptance

- Inclusion in PubMed, CAS, Scopus and Google Scholar

- Research which is freely available for redistribution 